\title{
Smart probe for simultaneous detection of copper ion, pyrophosphate, and alkaline phosphatase in vitro and in clinical samples
}

\author{
Sonia Kiran ${ }^{1} \cdot$ Renuka Khatik $^{1} \cdot$ Romana Schirhagl $^{2}$ \\ Received: 11 June 2019 / Revised: 1 July 2019 / Accepted: 9 July 2019 / Published online: 2 August 2019 \\ (C) The Author(s) 2019
}

\begin{abstract}
Wilson's disease (WD), which might lead to acute liver failure, is an inherited disorder characterized by accumulation of copper $\left(\mathrm{Cu}^{2+}\right)$ in the brain, the liver, and other vital organs. In the clinic, decreased serum alkaline phosphatase (ALP) concentration is used for WD diagnosis. But to the best of our knowledge, using a fluorescent probe to simultaneously detect multiple factors in WD (e.g., $\mathrm{Cu}^{2+}$, pyrophosphate (PPi), and ALP) has not been reported. Herein, we rationally designed a fluorescent switch (E)8-((4-methylbenzylidene)amino)napthalen-1-amine (L) and successfully applied it for sequential and selective detections of $\mathrm{Cu}^{2+}, \mathrm{PPi}$, and ALP in vitro, in living cells and synovial fluid samples with "Off," "On," and "Off" fluorescence signals, respectively. Considering the obvious correlations among $\mathrm{Cu}^{2+}$, $\mathrm{PPi}$, and ALP in WD, we envision that our fluorescent probe $\mathbf{L}$ could be applied to in vitro diagnosing WD in the near future.
\end{abstract}

Keywords Wilson's disease $\cdot$ Copper ion $\cdot$ Pyrophosphate $\cdot$ Alkaline phosphatase $\cdot$ Fluorescent probe

\section{Introduction}

Copper is present as trace element in the human body. It is crucial for various physiological activities like functioning of proteins, expressing genes [1], and operating of the human nerve system [2]. Dearth of copper ion $\left(\mathrm{Cu}^{2+}\right)$ results in myelopathy [3] and exalted level of $\mathrm{Cu}^{2+}$ may lead to kidney and liver damage [4]. For sensitive discernment of $\mathrm{Cu}^{2+}$, different techniques such as surface plasmon resonance (SPR) [5], atomic absorption/emission spectroscopy (AAS/AES) [6], inductively coupled plasma mass spectroscopy (ICPMS) [7], and surface-enhanced Raman scattering (SERS) [8] have been successfully applied hitherto. However, costly equipment and

Electronic supplementary material The online version of this article (https://doi.org/10.1007/s00216-019-02027-2) contains supplementary material, which is available to authorized users.

Romana Schirhagl

romana.schirhagl@gmail.com

1 Department of Chemistry, University of Science and Technology of China, \#96 Jinzhai Road, Hefei 230026, Anhui, China

2 University Medical Center Groningen, Groningen University, Antonius Deusinglaan 1,9713 AW Groningen, The Netherlands sophisticated and well-trained personnel are required for these approaches.

Small molecule-based (SMB) systems are potentially able to overcome the obstacles. For examples, nucleic acid sensors [9] and new "Off" (or "On") fluorescent probes [10-14] have been introduced for the detection of $\mathrm{Cu}^{2+}$ with excellent sensitivity and good accuracy. However, these systems also have some snags. Often they require harsh reaction conditions, tedious sample preparation procedures, and chemical and physical interference with coexisting metal ion or inadequate biocompatibility [15].

Beside cations, anions are also essential in biological processes and industrial units and have gained attention in the last decades [16]. One biologically significant anion is pyrophosphate (PPi) which is product of adenosine triphosphate (ATP) metabolism [17]. PPi concentration provides indispensible information about replication of DNA [18]. The eminent level of PPi in the synovial fluid has been suggested as a disease marker in arthritis patients; hence, PPi serves as biomarker for calcium pyrophosphate dihydrate (CPPD) crystal deposition or chondrocalcinosis $[19,20]$. Until now, various techniques had been used for PPi detection, such as colorimetric assays [21], electrooptical methods [22], and fluorescence assays [23]. Advantages of fluorescent chemosensors are their low cost, high spatial resolution and sensitivity, and short response 
time [24]. The strong binding interaction between metal ion and PPi opens different ways to design metal ion complexbased fluorescent switch as useful approach for PPi detection [25].

Alkaline phosphatase (ALP) is an indispensible enzyme which catalyzes the dephosphorylation of proteins, small molecules, and nucleic acids [26]. Deviated ALP level might induce various disorders such as diabetes, bone diseases, hepatobiliary disease, breast cancer, and prostatic cancer [27]. Hence, it is decisive to establish sensitive and simple methods for accurate detection of ALP level. Up to date, many different approaches have been applied to recognize ALP, such as electrochemical assays [28], fluorescence [29], chemiluminescence [30], SERS [31], and capillary electrophoresis [32]. The fluorescent assays of ALP have captivated much consideration due to their reliability, accessibility, and sensitivity [33]. Su et al. developed a carbon quantum dot-based fluorescent switch for ALP sensing [34-36]. Xiang and coworkers reported a fluorescent sensor for ALP quantification utilizing bright fluorescent nanosheets of g- $\mathrm{C}_{3} \mathrm{~N}_{4}$ [28]. Liang et al. utilize sol-gel transition (hydrogelation) with "Turn-Off" fluorescence for quantitative analysis of ALP both in vitro and in LoVo cells [37].

Wilson's disease (WD) is an inherited disorder characterized by an excess of copper in the liver and brain. Severe WD might lead to acute liver failure which is often fatal. In genomics, WD is induced by the mutation in the Atp7b gene which codes the copper-transporting P-type ATPase involved in cellular copper excretion [38]. Patients suffering from Wilson's disease exhibit high urinary copper levels (> $100 \mathrm{mg} /$ day, compared with 20 $40 \mathrm{mg} /$ day in healthy individuals) and increased serumfree copper levels (> $25 \mu \mathrm{g} / \mathrm{dL}$, compared with 11-25 $\mu \mathrm{g}$ / $\mathrm{dL}$ in healthy individuals) [38]. As a result, decreased serum ALP concentration (the ratio between serum ALP to bilirubin is $<2$ ) and non-immune hemolytic anemia are often seen in WD and the former is used for WD diagnosis in the clinic [39].

Considering the relationships among $\mathrm{Cu}^{2+}, \mathrm{PPi}$, and ALP in $\mathrm{WD}$, we designed a fluorescent switch for the sequential and selective detections of these three analytes. Such a combined detection scheme has already developed before making use of different kinds of nanoparticles. More specifically, Mo oxide quantum dots [40], carbon dots [41-43], Au nanoclusters [44], carbon dots and Au nanoclusters [45], silver nanocluster [46], upconversion nanoparticle [47], Eu(DPA)3@Lap nanohybrid material [48], or anionic conjugated polymers [49] were utilized. Several of these have superior sensitivity. However, these are comparably large and thus sensing resolution is limited. Also most of them contain heavy metals which can be a biocompatibility concern. The existing literature is compared with this work in Table 1.
Here, a fluorescent probe (E)-8-((4-methylbenzylidene) amino)napthalen-1-amine ( $\mathbf{L})$ which could specifically bind with $\mathrm{Cu}^{2+}$ was rationally designed and synthesized (see Scheme 1). Chelation between $\mathrm{Cu}^{2+}$ and $\mathbf{L}$ yields the $\mathbf{L}$ $\mathrm{Cu}^{2+}$ complex. In this configuration, the fluorescence is "Off." Due to the stronger binding affinity of $\mathrm{PPi}-\mathrm{Cu}^{2+}$ than $\mathbf{L}-\mathrm{Cu}^{2+}$, addition of PPi to above solution dissociates the $\mathbf{L}$ $\mathrm{Cu}^{2+}$ complex and turns the fluorescence "On" again. Interestingly, further added ALP will hydrolyze PPi in the PPi- $\mathrm{Cu}^{2+}$ complex, freeing $\mathrm{Cu}^{2+}$ to re-chelate with $\mathbf{L}$ and turn the fluorescence "Off." With this fluorescence "Off"-“On"-“Off" property, the fluorescence switch $\mathbf{L}$ was successfully applied for sequential and selective detection of $\mathrm{Cu}^{2+}, \mathrm{PPi}$, and ALP in vitro and in living cells. A slightly more complex molecule with a similar purpose was reported earlier this year by Pandith et al. [50]. They used a doubly armed hydrazone-based probe (FLRHYDDFP) to continuously detect $\mathrm{Cu}^{2+}, \mathrm{PPi}$, and ALP with high sensitivity. Compared with Pandith et al., we designed a Schiff base derivative, which has excellent ability for metal ion detection with highly flexible, efficient, selective, and easily applicable structure [51-53]. Our probe was synthesized easily and cheaply by one step. Besides in vitro detection and cell imaging, we also applied our probe for detection of PPi in biological synovial fluid samples. What's more, we carried out the computational calculations to elaborate the mechanism of fluorescence quenching by ligand to metal charge transfer (LMCT).

\section{Experimental section}

\section{General methods}

\section{Materials}

Recombinant intestinal ALP was purchased from BaoMan Inc. (Shanghai, China) (one unit is the enzyme activity that cleaves $1 \mu \mathrm{mol}$ of the standard substrate per minute at $37^{\circ} \mathrm{C}$ ). The phosphatase inhibitor complex II was purchased from Sangong Biotech Inc. (Shanghai, China) (every $10 \mu \mathrm{L}$ ALP inhibitor complex II in culture medium containing $1 \times 10^{7}$ cells). All the starting materials were obtained from Sigma or Sangon Biotech. Commercially available reagents were used without further purification, unless noted otherwise.

\section{Methods}

${ }^{1} \mathrm{H}$ NMR and ${ }^{13} \mathrm{C}$ NMR spectra were recorded on a Bruker Model AV 300 system. ESI mass spectra were obtained on a Finnigan LCQ Advantage ion trap mass spectrometer (Thermo Fisher Corporation) that was equipped with a standard ESI source, respectively. A F-4600 fluorescence spectrophotometer (Hitachi High-Technologies Corporation, Japan) 
Table 1 comparison of combined essays (for more comparisons with single component sensors, see Electronic Supplementary Material (ESM))

\begin{tabular}{lllll}
\hline Ref & LOD & Linear range & Response time & Sample \\
\hline 40 & $0.02 \mathrm{U} / \mathrm{L}$ & $0.1-5 \mathrm{U} / \mathrm{L}$ & $10 \mathrm{~min}$ & Human serum \\
41 & $\mathrm{NA}$ & $\mathrm{NA}$ & $10 \mathrm{~min}$ & Cell cultures \\
42 & $0.1 \mathrm{U} / \mathrm{L}$ & $0.1-75 \mathrm{U} / \mathrm{L}$ & Minutes & Chemical samples \\
43 & $0.05 \mathrm{U} / \mathrm{L}$ & $0.12-15 \mathrm{U} / \mathrm{L}$ & Minutes & Mineral water \\
44 & $0.000005 \mathrm{U} / \mathrm{L}$ & $0.03-3 \mathrm{U} / \mathrm{mL}$ & $30 \mathrm{~min}$ & Clinical samples \\
45 & $0.019 \mathrm{U} / \mathrm{mL}$ & $0.0625-0.875 \mathrm{U} / \mathrm{mL}$ & $10 \mathrm{~min}$ & Diluted bovine serum/cells \\
46 & $0.5 \mathrm{U} / \mathrm{L}$ & 0.5 to $60 \mathrm{U} / \mathrm{L}$ & $60 \mathrm{~min}$ & Chemical samples \\
47 & $20 \mathrm{nM}$ & $20-100 \mathrm{nM}$ & $10 \mathrm{~min}$ & Cells \\
This work & $0.4 \mathrm{U} / \mathrm{mL}$ & $0.4-3.0 \mathrm{U} / \mathrm{mL}$ & $30 \mathrm{~min}$ & Clinical samples \\
\hline
\end{tabular}

was used to record fluorescence spectra with excitation wavelengths set to $310 \mathrm{~nm}$. Cell imaging was carried out on a IX71 fluorescence microscope (Olympus, Japan).

\section{Cell experiments}

\section{MTT assay}

The cervical cancer HeLa cell lines of passage four were kindly provided by Prof Wang, School of Life Science, University of Science and Technology of China. HeLa cells were cultured in Dulbecco's modified Eagle medium (DMEM), augmented with streptomycin $(100 \mu \mathrm{g} / \mathrm{mL})$ and $10 \%$ fetal bovine serum. The cells were cultured in dishes and stored at $37{ }^{\circ} \mathrm{C}$ with $5 \%$ $\mathrm{CO}_{2}$. 3-(4,5-Dimethylthiazol-2-yl)-2,5-diphenyltetrazolium bromide (MTT) assay was used to calculate the cytotoxicity of the probe. HeLa cells were grown into a 96-well cell culture plate for $12 \mathrm{~h}$ with $3 \times 10^{3}$ cells/well concentration in humid atmosphere. The solutions of $\mathbf{L}$ in $100 \mu \mathrm{L}$ DMEM $(100 \mu \mathrm{L} /$ well) at various concentrations $(6.25,12.5,25,50$, and $100 \mu \mathrm{M}$ ) were added to each well carefully. These cultured plates were incubated in humid atmosphere for another 24, 48, or $72 \mathrm{~h}$. In total, $5 \mathrm{mg} / \mathrm{mL}$ MTT $(10 \mu \mathrm{L} /$ well $)$ solution was added to every well of the 96-well plate. After 4-h incubation, DMSO $(100 \mu \mathrm{L})$ was added to each well to dissolve the formazan. The data were obtained at 570/680 nm using an enzyme-linked immunosorbent assay (ELISA) reader (VARIOSKAN FLASH). The following formula was used to calculate the percentage viability of cells: viability $(\%)=($ mean of absorbance value of treatment group/mean of absorbance value of control) $\times 100$.

\section{Cell imaging}

Cultured HeLa cell dishes were carefully washed with PBS ( $\mathrm{pH} 7.4$ ) and then $10 \mu \mathrm{M} \mathbf{L}$ in serum-free DMEM was added to each cell culture dish. These dishes were stored at $37{ }^{\circ} \mathrm{C}$ for $1 \mathrm{~h}$ prior to imaging. For $\mathrm{Cu}^{2+}$ imaging, cells were again incubated for $30 \mathrm{~min}$ with $\mathrm{Cu}^{2+}$ at a concentration of 10,20 , or $30 \mu \mathrm{M}$ in serum-free DMEM followed by imaging. For PPi imaging, abovementioned cells were further incubated with various concentrations of PPi $(20 \mu \mathrm{M}, 40 \mu \mathrm{M}$, or $60 \mu \mathrm{M})$ for $30 \mathrm{~min}$ prior to imaging. Later, these cells were split into two groups (with/without ALP inhibitor) for time course fluorescence imaging of ALP activity at 30, 60, and $120 \mathrm{~min}$.

\section{Fluorescence sensing of PPi in synovial fluids of arthritis patients}

The synovial fluids of arthritis patients were collected from the Shanghai Ninth Hospital, Shanghai Jiao Tong University School of Medicine. The patients have given their consent for the procedure and the doctors have the respective permissions to draw synovial fluids. Two samples were from arthritis patients while one sample was obtained from a healthy person as control. Prior to the fluorescence sensing, the synovial fluid samples were centrifuged with an ultrafiltration device (molecular weight cutoff $50 \mathrm{kDa}$; Millipore Amicon Ultra) at $6000 \mathrm{rpm}$ for 20 min. Then, these samples were diluted with HEPES buffer ( $\mathrm{pH} 7.4,10 \mathrm{mM})$ in order to be consistent with the linear range of our method. For the fluorescent sensing of PPi in the synovial fluids, $10 \mu \mathrm{L}$ diluted synovial fluid was added to the solution containing $5 \mu \mathrm{M} \mathrm{L}$ and $5 \mu \mathrm{M} \mathrm{Cu}^{2+}$ in HEPES buffer (pH 7.4, $10 \mathrm{mM}$ ) and incubated for $30 \mathrm{~min}$.

\section{Density functional theory calculations}

To better evaluate the nature of coordination between $\mathbf{L}$ and $\mathrm{Cu}^{2+}$, the optimized structures of $\mathbf{L}$ and its corresponding $\mathrm{Cu}^{2+}$ complex have been calculated. All calculations were carried out by density functional theory (DFT) formalism implemented in Gaussian 09 quantum chemistry software package. Time-dependent DFT (TDDFT) calculation at the hybrid function density functional theory B3LYP level was carried out to find the excited states; molecular orbitals were built with the GaussView package. 
Scheme 1 Schematic presentation of fluorescence "Off," "On," and "Off" of L for selective detections of $\mathrm{Cu}^{2+}, \mathrm{PPi}$, and ALP respectively in aqueous buffer and in cells
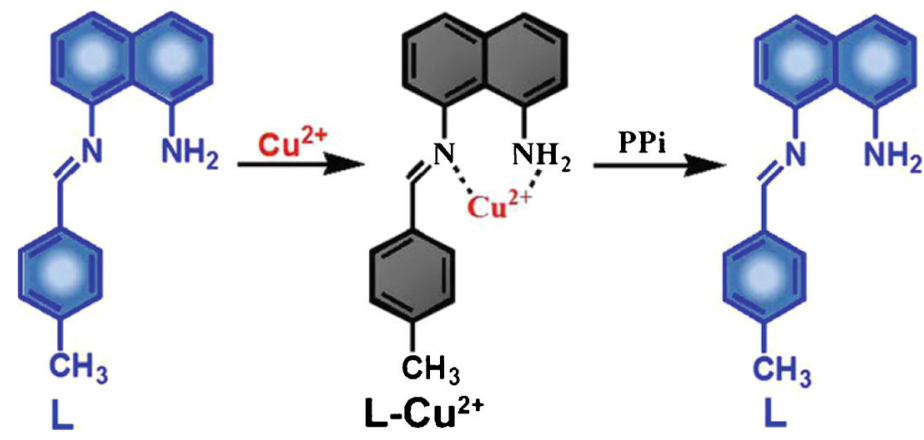

\section{Syntheses and characterizations of $\mathrm{L}$ and $\mathrm{L}-\mathrm{Cu}^{2+}$}

The study was started with the synthesis of L. Briefly, 1,8-diaminonaphthalene in ethanol was added dropwise to an equivalent 4-methyl benzaldehyde and the colorless solution turned to light yellowish rapidly. Then, the mixture was heated to reflux for $2 \mathrm{~h}$ (ESM Scheme S1). The pure light yellowish solid product $\mathbf{L}$ was obtained and characterized after purification (ESM Figs. S1-S3). After synthesis, we first investigated the spectroscopic properties of $\mathbf{L}$. The excitation spectrum of $\mathbf{L}$ in HEPES buffer (10 mM, 4\% DMSO) was recorded (ESM Fig. S4). Further on, the absorption spectrum was observed at various $\mathrm{pH}$ values ranging from 5 to 9 in HEPES buffer (10 $\mathrm{mM}, 4 \% \mathrm{DMSO}$ ) at RT. UV-vis spectra of $\mathbf{L}$ at various $\mathrm{pH}$ values did not show obvious changes, suggesting that the chemical structure of $\mathbf{L}$ was stable to $\mathrm{pH}$ variations (ESM Fig. S5).

\section{Results and discussion}

\section{In vitro detection of $\mathrm{Cu}^{2+}$}

After confirming the fluorescence property of $\mathbf{L}$, we tested its capability for $\mathrm{Cu}^{2+}$ detection. An equivalent amount of $\mathrm{Cu}^{2+}$ was added into the abovementioned $\mathbf{L}$ solution. We observed a sharp decrease of the fluorescence (ESM Fig. S6A), probably due to entrapment of $\mathrm{Cu}^{2+}$ in $\mathbf{L}$ to form $\mathbf{L}-\mathrm{Cu}^{2+}$ complex. Photographs showed that the light yellowish solution of $\mathbf{L}$ changed to a blackish green one after $\mathrm{Cu}^{2+}$ addition (ESM Fig. S6B). In detail, with the gradual addition of $\mathrm{Cu}^{2+}$ (from 0 to $40 \mu \mathrm{M}$ ), we observed a continuous decrease of the fluorescence peak of $40 \mu \mathrm{M}$ L, accompanied by a $23-\mathrm{nm}$ redshift from 415 to $438 \mathrm{~nm}$ (Fig. 1a). The FI at $415 \mathrm{~nm}$ and $\mathrm{Cu}^{2+}$ concentration showed a linear relation $\left(Y=3095.32-74.35 * X, R^{2}=\right.$ $0.98)$ over the range of $0-40 \mu \mathrm{M}$ and the limit of detection (LOD) of $\mathrm{Cu}^{2+}$ was measured to be $2.60 \mu \mathrm{M}$ according to the $3 \sigma$ method (Fig. 1b), which is comparable with those of recently reported fluorescence probes for $\mathrm{Cu}^{2+}$ detection (Tab. S1). When the $\mathrm{Cu}^{2+}$ concentration exceeded $40 \mu \mathrm{M}\left(\mathbf{L}: \mathrm{Cu}^{2+}=1: 1\right)$, no further decrease of the FI was observed, suggesting the binding stoichiometry between $\mathbf{L}$ and $\mathrm{Cu}^{2+}$ is $1: 1$. Electrospray ionization mass spectrum (ESI/MS) of $\mathbf{L}$ after the addition of 1 equiv. $\mathrm{Cu}^{2+}$ showed the dominant ionic peak in the spectrum has a $m / z$ value of 393.08 , which corresponds to [L$\mathrm{Cu}^{2+}$ ] (ESM Fig. S7). Job's plot analysis also indicated that the binding stoichiometry between $\mathbf{L}$ and $\mathrm{Cu}^{2+}$ is $1: 1$ (ESM Fig. S8). According to the reported method [54], the binding constant was calculated to be $1.263 \times$ $10^{5} \mathrm{M}^{-1}$. To further confirm the formation of the complexes, we directly synthesized $\mathrm{CuCl}_{2} \mathbf{L}$ complex by heating and stirring the dichloromethane/methanol solution of $\mathbf{L}$ with $\mathrm{CuCl}_{2}(1: 1.2)$ at $50{ }^{\circ} \mathrm{C}$ for $3 \mathrm{~h}$ [55]. Transmission electron microscopy (TEM) images revealed the nanorod structure of $\mathrm{CuCl}_{2} \mathbf{L}$ with an average diameter of $65.3 \pm 3.0 \mathrm{~nm}$ (ESM Fig. S9A). Energy-dispersive Xray spectrometer (EDS) spectra of $\mathrm{CuCl}_{2} \mathbf{L}$ proved the existence of $\mathrm{Cu}$ in the complex (ESM Fig. 9B). The Xray diffraction (XRD) analysis was employed to further identify $\mathrm{CuCl}_{2} \mathbf{L}$ complex formation. The XRD patterns of ligand, $\mathrm{CuCl}_{2}$, and $\mathbf{L}-\mathrm{Cu}^{2+}$ complex were carefully analyzed, We observed that there were no specific peaks for ligand $\mathbf{L}$, suggesting that the ligand is non-crystalline in nature. For $\mathrm{CuCl}_{2}$, an obvious clear peak was observed $[56,57]$. However, for $\mathbf{L}-\mathrm{Cu}^{2+}$ complex, we observed that some peaks were quite similar to $\mathrm{CuCl}_{2}$ peaks while some new peaks were also observed, suggesting that $\mathbf{L}-\mathrm{Cu}^{2+}$ complex is successfully formed (ESM Fig. S10).

To evaluate the activity of newly designed probe, selectivity and interference are two important parameters. Especially for probes having biomedical applications, a selective response toward the target over various competing species is needed. Therefore, the selectivity study of $\mathbf{L}$ to $\mathrm{Cu}^{2+}$ over various metal ions, e.g., $\mathrm{Co}^{2+}, \mathrm{Zn}^{2+}, \mathrm{Ni}^{2+}$, $\mathrm{Mg}^{2+}, \mathrm{Ag}^{+}, \mathrm{Pb}^{2+}, \mathrm{Cr}^{2+}$, and $\mathrm{Cd}^{2+}$, was conducted. Moreover, interference from all above metal ions with the $\mathrm{Cu}^{2+}$ detection by $\mathbf{L}$ was investigated. As shown in Fig. 1c, $\mathbf{L}$ showed excellent selectivity and interference for $\mathrm{Cu}^{2+}$ detection among abovementioned metal ions. 
Besides, photographs showed clear color changes in cuvettes which contained $\mathrm{Cu}^{2+}$ alone or mixed with other metal ions; fluorescence of the samples under a UV lamp echoed that only the fluorescence from above two cuvettes was turned "Off" (Fig. 1d). These results confirmed the excellent selectivity and interference of $\mathbf{L}$ for $\mathrm{Cu}^{2+}$ detection in vitro.

\section{Computational study}

To elaborate the mechanism of fluorescence quenching by the energy and/or charge transfer model, we carried out the computational calculations (Fig. 2). The optimized structures of $\mathbf{L}$ and $\mathbf{L}-\mathrm{Cu}^{2+}$ were calculated at ground state (Fig. 2a). Timedependent DFT (TDDFT) calculations at the hybrid DFT B3LYP level were carried out to find out the excited states. From this calculation, we noticed that the fluorescence quenching by $\mathrm{Cu}^{2+}$ could be rationalized in terms of the occupancy of the frontier orbitals. Figure $2 \mathrm{~b}$ shows the calculated frontier molecular orbitals (HOMO, LUMO, LUMO+1, LUMO+2) of $\mathbf{L}$ and $\mathbf{L}-\mathrm{Cu}^{2+}$. These HOMO, LUMO, and $\mathrm{LUMO}+1$ of both $\mathbf{L}$ and $\mathbf{L}-\mathrm{Cu}^{2+}$ showed similar electron density distribution. The LUMO+2 of $\mathbf{L}$ showed equally distributed density over the whole structure while that of $\mathbf{L}-\mathrm{Cu}^{2+}$ showed the electron density particularly over methylbenzene ring and $\mathrm{Cu}^{2+}$ ion, suggesting that the electron was transferred from the diaminonaphthalene ring to $\mathrm{Cu}^{2+}$ ion. This ligand to metal charge transfer (LMCT) mechanism caused the fluorescence quenching of $\mathbf{L}$ upon addition of $\mathrm{Cu}^{2+}[58]$.

\section{In vitro detection of PPi}

As mentioned above, the binding affinity between $\mathrm{Cu}^{2+}$ and PPi is larger than that between $\mathbf{L}$ and $\mathrm{Cu}^{2+}[59]$. Thus, addition of PPi to above $\mathbf{L}-\mathrm{Cu}^{2+}$ solution will dissociate the $\mathbf{L}-\mathrm{Cu}^{2+}$ complex to form new PPi- $\mathrm{Cu}^{2+}$ complex and turns the $\mathbf{L}$ fluorescence "On" again for PPi detection. As shown in Fig. 3a, with the increase of PPi concentration, fluorescence emission of the $\mathbf{L}-\mathrm{Cu}^{2+}$ complex at $438 \mathrm{~nm}$ gradually increased accompanied by a $9-\mathrm{nm}$ blueshift from 438 to $430 \mathrm{~nm}$. Thus, a calibration curve of the FI of the $\mathbf{L}-\mathrm{Cu}^{2+}$ complex at $438 \mathrm{~nm}$ for the determination of PPi in aqueous buffer was obtained (inset of Fig. 2a). It showed a linear relationship between the FI and PPi concentrations $\left(Y=421.17-8.63^{*} X, R^{2}=0.99\right)$ over the range of $0-60 \mu \mathrm{M}$. The LOD of PPi in this assay was calculated to be $0.31 \mu \mathrm{M}(S / N=3)$, which is comparable with those of recently reported fluorescence probes for PPi detection (Tab. S2). Moreover, the selectivity of $\mathbf{L}-\mathrm{Cu}^{2+} \mathrm{com}$ plex to PPi among different common anions $\left(\mathrm{NO}_{3}{ }^{-}, \mathrm{SO}_{4}{ }^{2-}\right.$, $\mathrm{F}^{-}, \mathrm{\Gamma}, \mathrm{Br}^{-}, \mathrm{Cl}^{-}$, and $\mathrm{AcO}^{-}$in this work) was carefully studied. As shown in Fig. 3b, among the tested anions, only PPi induced a turned "On" fluorescence, suggesting excellent selectivity of the $\mathbf{L}-\mathrm{Cu}^{2+}$ complex for PPi detection.

\section{Detecting pyrophosphate anion in synovial fluid samples}

The potential importance of our proposed design is its ability to operate in biological samples. To further
Fig. 1 a Fluorescence spectra of $40 \mu \mathrm{M} \mathrm{L}$ in the presence of $\mathrm{Cu}^{2+}$ $(0,5,10,15,20,25,30,35$, or $40 \mu \mathrm{M})$ in HEPES buffer ( $\mathrm{pH} 7.4$, $10 \mathrm{mM}, 4 \%$ DMSO) at RT. $\lambda_{\mathrm{ex}}=$ $310 \mathrm{~nm}$. b The fitted calibration line in the linear region of 0 $40 \mu \mathrm{M} \mathrm{Cu}^{2+}$. c Fluorescence emissions of $\mathrm{Cu}^{2+}$ at RT were measured with $40 \mu \mathrm{M} \mathrm{L}$ before and after the addition of 3 equiv. of various ions $\mathrm{CMg}^{2+}, \mathrm{Cr}^{2+}, \mathrm{Cd}^{2+}$, $\mathrm{Ag}^{+}, \mathrm{Pb}^{2+}, \mathrm{Zn}^{2+}, \mathrm{Ni}^{2+}, \mathrm{Co}^{2+}$, $\mathrm{Ca}^{2+}, \mathrm{Fe} 2+$, and $\mathrm{Fe}^{3+}$ or mix) in HEPES buffer (pH 7.4, $10 \mathrm{mM}$ ). $\lambda_{\text {ex }}=310 \mathrm{~nm}, \lambda_{\text {em }}=415 \mathrm{~nm}$. d Fluorescence responses of $\mathbf{L}$ to various ions under a UV lamp (top row) and photographs of $\mathbf{L}$ in presence of different metals (bottom row). These experiments were performed in triplicate; error bar represents standard deviation
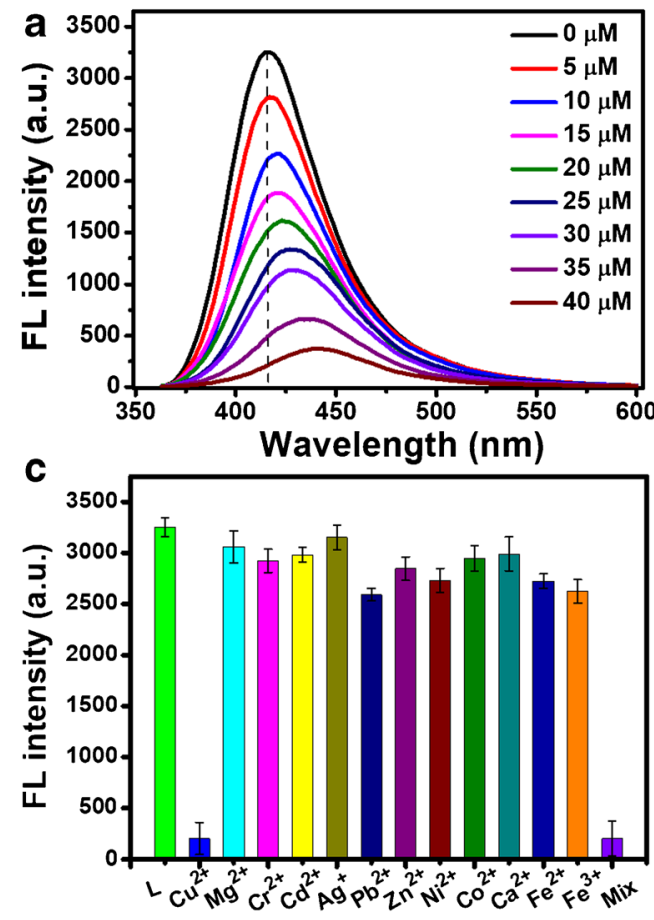
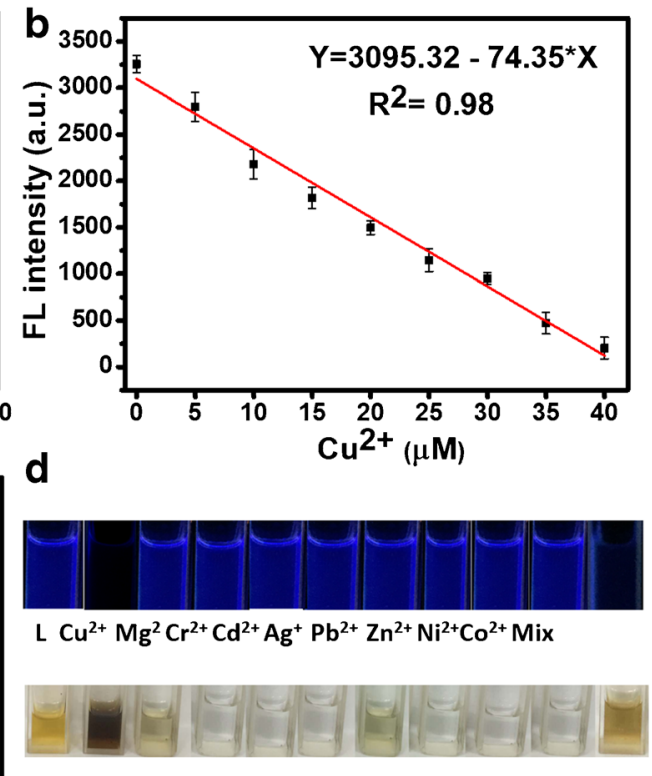

$\mathrm{L} \mathrm{Cu}{ }^{2+} \mathrm{Mg}^{2} \mathrm{Cr}^{2+} \mathrm{Cd}^{2+} \mathrm{Ag}^{+} \mathrm{Pb}^{2+} \mathrm{Zn}^{2+} \mathrm{Ni}^{2+} \mathrm{Co}^{2+} \mathrm{Mix}$ 
Fig. 2 a Optimized structures of $\mathbf{L}$ (left side) and $\mathbf{L}-\mathrm{Cu}^{2+}$ (right side). b B3LYP/6-31G*-

calculated molecular orbitals of $\mathbf{L}$ (top row) and $\mathbf{L}-\mathrm{Cu} 2+$ (bottom row) a
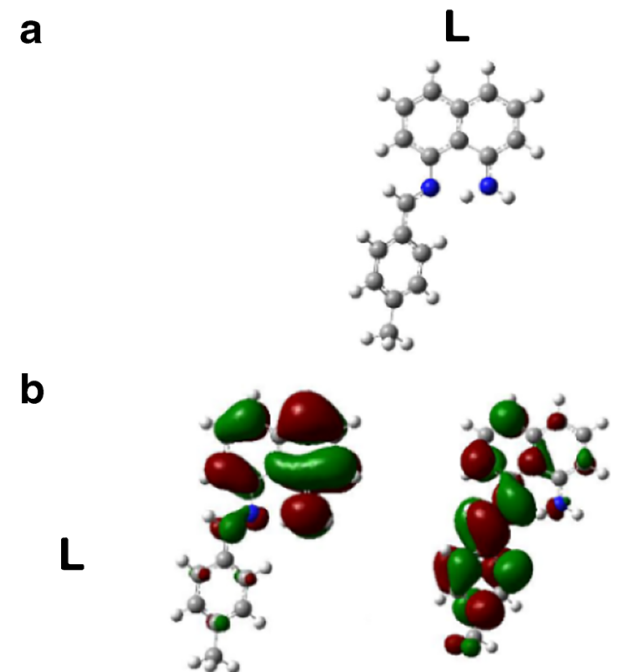

HOMO
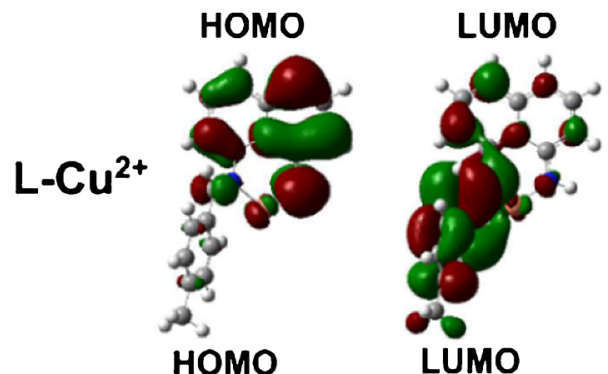

LUMO
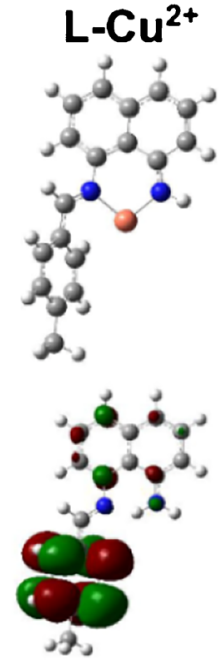

LUMO + 1

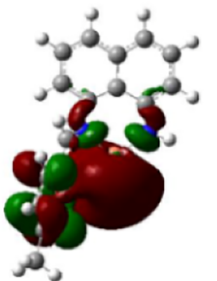

LUMO +1

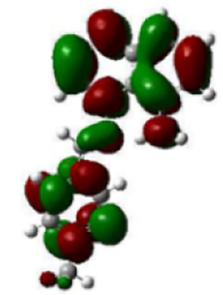

LUMO +2

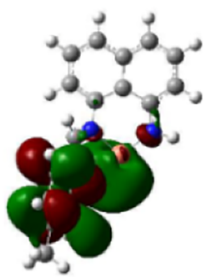

LUMO +2 demonstrate the potential application of our method in clinical samples, we detected PPi in synovial fluids from arthritis patients and healthy controls. As shown in Fig. 4, when $\mathbf{L}-\mathrm{Cu}^{2+}$ complex was added to the synovial fluid of healthy control, we observed a 1.2-fold increase of FI. Compare with the healthy control, the $\mathrm{Fl}$ of $\mathbf{L}-\mathrm{Cu}^{2+}$ complex with two synovial fluid samples from arthritis patients could further increase $\sim 1.4$ and $\sim 1.8$-fold, suggesting the elevated level of PPi in synovial fluids from arthritis patients. These results promote our findings that $\mathbf{L}$ $\mathrm{Cu}^{2+}$ complex is quite suitable to apply for PPi detection in arthritis patients due to strong binding interaction between $\mathrm{Cu}^{2+}$ and PPi. Synovial fluid is a very complex medium and the redshift might be attributed to adsorption of medium compounds to the molecule or interaction with medium compounds.

\section{In vitro detection of ALP}

Considering that ALP is able to dephosphorylate the PPi in the PPi- $\mathrm{Cu}^{2+}$ complex to free $\mathrm{Cu}^{2+}$ to re-chelate with $\mathbf{L}$, we used the abovementioned mixture solution for quantitative detection of ALP activity with fluorescence "Turn-Off." Following the formation of $\mathrm{Cu}^{2+}-\mathrm{PPi}$, various concentrations of ALP $(0.4$ to $3.0 \mathrm{U} / \mathrm{mL}$ ) were added and the fluorescence spectra were recorded after 30-min incubation at RT. As shown in Fig. 5a, with the increase of ALP concentration, $\mathrm{Fl}$ of the mixture solution at $406 \mathrm{~nm}$ gradually decreased. By correlating the
Fig. 3 a Fluorescence spectra of $40 \mu \mathrm{M} \mathrm{L}-\mathrm{Cu}^{2+}$ in the presence of PPi $(0,10,20,30,40,50$, or $60 \mu \mathrm{M})$ in HEPES buffer ( $\mathrm{pH} 7.4$, $10 \mathrm{mM}, 4 \%$ DMSO $)$ at RT $\left(\lambda_{\text {ex }}=\right.$ $310 \mathrm{~nm}$ ). Inset: the fitted calibration line in the linear region of 0-60 $\mu \mathrm{M}$ PPi. b FL of $40 \mu \mathrm{M}$ $\mathbf{L}-\mathrm{Cu}^{2+}$ complex at $438 \mathrm{~nm}$ with/ without the addition of 5 equiv. of various common anions
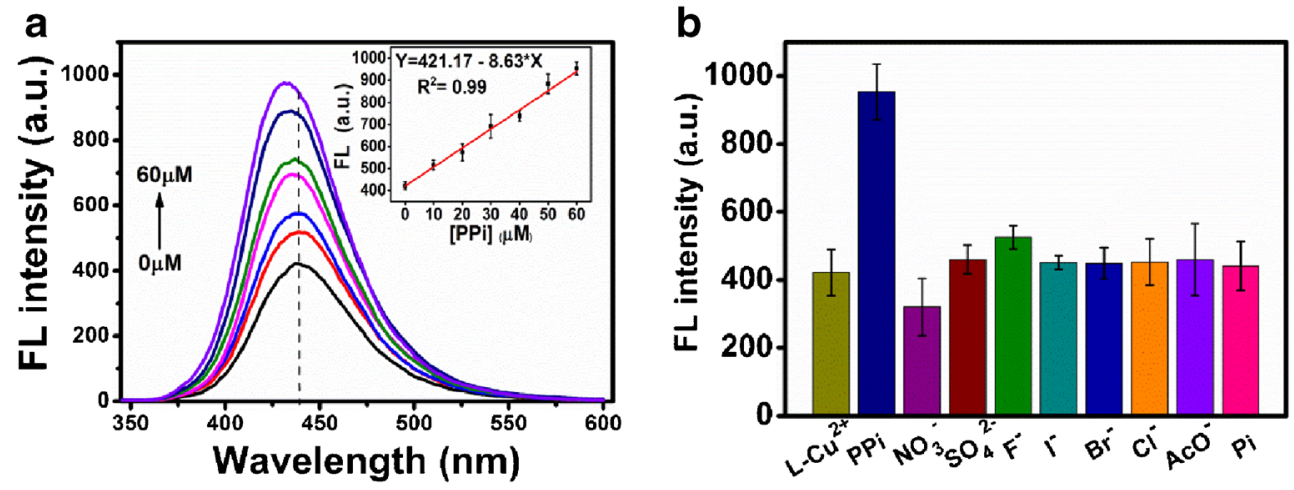


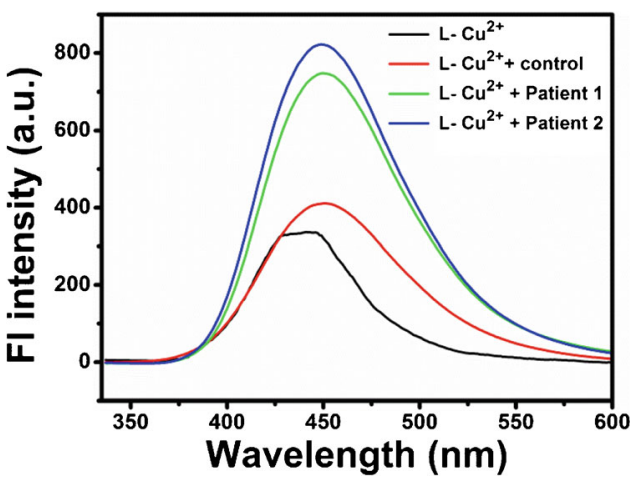

Fig. 4 The fluorescence spectra of the reaction system carried out in synovial fluid from $\mathbf{L}-\mathrm{Cu}^{2+}$ complex, healthy control, and two arthritis patients

FI the mixture solution at $406 \mathrm{~nm}$ with the concentration of ALP, we obtained a calibration curve for the determination of ALP in aqueous buffer (inset in Fig. 5a). A linear relationship between the $\mathrm{Fl}$ at $406 \mathrm{~nm}$ and ALP concentration ( $Y=$ $\left.1006.44-208.43 * X, R^{2}=0.99\right)$ was obtained $(0.4-3.0 \mathrm{U} /$ $\mathrm{mL})$, with LOD value $0.05 \mathrm{U} / \mathrm{mL}(S / N=3)$ of ALP in this assay, which is comparable with those of recently reported fluorescence probes for ALP detection (Tab. S3). Selectivity study of as-formed $\mathrm{Cu}^{2+}$-PPi complex in the solution to ALP over various enzymes (trypsin, lysozyme, caspase-3, and thrombin in this work) indicated that the mixture solution is selective for ALP detection in vitro with fluorescence "TurnOff" property (Fig. 5b).

\section{Sequential imaging of $\mathrm{Cu}^{2+}$ and PPi in living cells}

Before cell imaging studies, cytotoxicity of $\mathbf{L}$ was investigated on living HeLa cells. MTT results indicated that, up to $100 \mu \mathrm{M}$ and $72 \mathrm{~h}, \mathbf{L}$ did not impose obvious cytotoxicity on the cells, suggesting $10 \mu \mathrm{M} \mathbf{L}$ was safe for live cell imaging

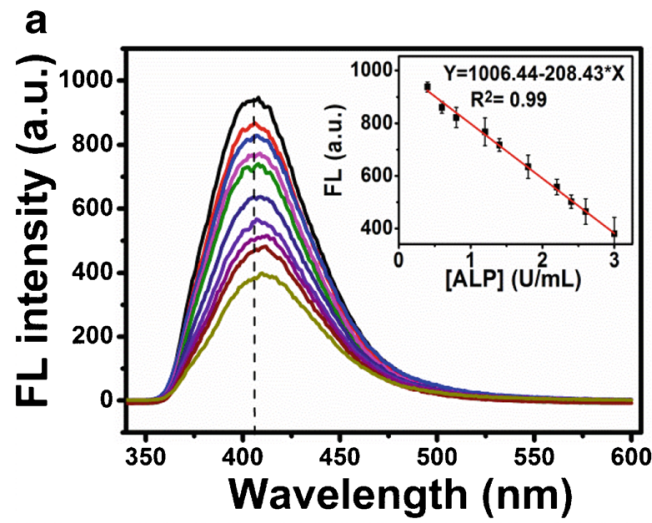

Fig. 5 a Fluorescence spectra of $40 \mu \mathrm{M} \mathrm{L}-\mathrm{Cu}^{2+}+60 \mu \mathrm{M}$ PPi in the presence of ALP at different concentrations $(0.4,0.6,0.8,1.2,1.4,1.8$, 2.2, 2.4, 2.6, or 3.0 U/mL) in HEPES buffer ( $\mathrm{pH} 7.4,10 \mathrm{mM}, 4 \%$ DMSO) at RT. $\lambda_{\mathrm{ex}}=310 \mathrm{~nm}$. Inset: the fitted calibration line in the linear region of
(ESM Fig. S11). HeLa cells were incubated with $10 \mu \mathrm{M} \mathrm{L}$ at $37^{\circ} \mathrm{C}$ for $1 \mathrm{~h}$ in serum-free DMEM and then washed with PBS for three times prior to imaging. Bright blue fluorescence from cell cytoplasm was observed, suggesting our probe $\mathbf{L}$ is cell permeable (left column of Fig. 6). Then, the cells were incubated with $\mathrm{Cu}^{2+}(0,10,20$, or $30 \mu \mathrm{M})$ at $37^{\circ} \mathrm{C}$ for $30 \mathrm{~min}$. Fluorescence cell imaging showed that the $\mathrm{Fl}$ gradually decreased with the increase of $\mathrm{Cu}^{2+}$ concentration (ESM Fig. S12) and was effectively quenched at $\mathrm{Cu}^{2+}$ concentration of $30 \mu \mathrm{M}$ (ESM Fig. S12 and the middle column of Fig. 6). The average FL of HeLa cells in ESM Fig. S12 was measured by using Image J and is summarized in ESM Fig. S13. The Fl of $\mathbf{L}$ in Hela cells had a 7.4-fold decrease by $30 \mu \mathrm{M} \mathrm{Cu}^{2+}$. After that, the $30 \mu \mathrm{M} \mathrm{Cu}^{2+}$-treated cells were incubated with various concentrations of PPi at $0,20,40$, or $60 \mu \mathrm{M}$ for another $30 \mathrm{~min}$ prior to imaging. Clearly, we found that cell fluorescence gradually turned "On" again (ESM Fig. S14) and reached its plataeu at $60 \mu \mathrm{M}$ PPi concentration (ESM Fig. S14 and the right column of Fig. 6). The average FL of HeLa cells in ESM Fig. S14 was measured by using ImageJ and is summarized in ESM Fig. S15. The Fl of $\mathbf{L}-\mathrm{Cu}^{2+}$ in Hela cells had a 7.6-fold increase by $60 \mu \mathrm{M}$ PPi. With the "Off" and "On" fluorescence property of $\mathbf{L}$ after $\mathrm{Cu}^{2+}$ and PPi additions, we successfully applied $\mathbf{L}$ for imaging $\mathrm{Cu}^{2+}$ and PPi in living cells.

\section{Imaging of ALP in living cells}

In order to apply our probe for imaging ALP activity in living HeLa cells, we split above PPi-treated cells into two groups: one group was treated with ALP inhibitor prior to imaging while the other was without any pretreatment. In detail, the $30 \mu \mathrm{M} \mathrm{Cu}^{2+}$-treated and $60 \mu \mathrm{M}$ PPi-treated cells were incubated with/without phosphatase inhibitor complex II $(10 \mu \mathrm{L}$ ALP inhibitor complex II in $1 \mathrm{~mL}$ culture medium) and

b

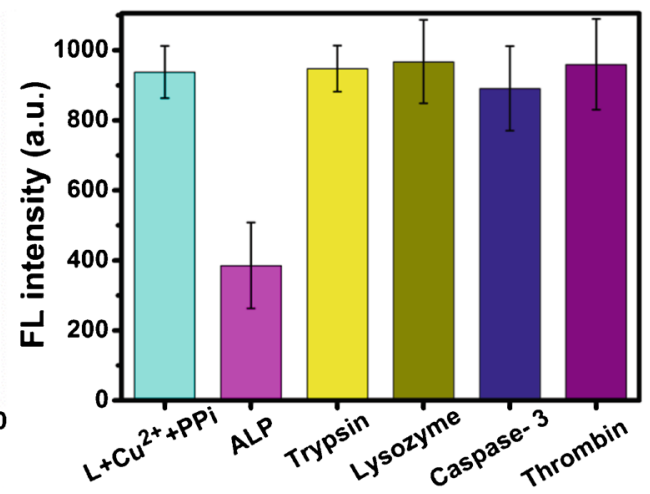

0.4-3.0 U/mL ALP. b FL of $40 \mu \mathrm{M} \mathrm{L}-\mathrm{Cu}^{2+}+60 \mu \mathrm{M}$ PPi solution at $406 \mathrm{~nm}$ in the presence of ALP $(3 \mathrm{U} / \mathrm{mL})$, trypsin $(50 \mathrm{U} / \mathrm{mL})$, lysozyme $(10 \mathrm{mg} / \mathrm{mL})$, caspase-3 $(50 \mathrm{U} / \mathrm{mL})$, and thrombin $(50 \mu \mathrm{M})$ 
Fig. 6 Fluorescence images (top row) and merged (DIC + FL) images (bottom row) of HeLa cells incubated with $10 \mu \mathrm{M} \mathrm{L}$ in serum-free DMEM for $1 \mathrm{~h}$ at $37^{\circ} \mathrm{C}$, washed with PBS (left column), added with $30 \mu \mathrm{M} \mathrm{Cu}^{2+}$ for 30 min (middle column) and then $60 \mu \mathrm{M}$ PPi for another 30 min (right column) in serumfree DMEM at $37^{\circ} \mathrm{C}$ prior to imaging. Scale bar: $20 \mu \mathrm{m}$

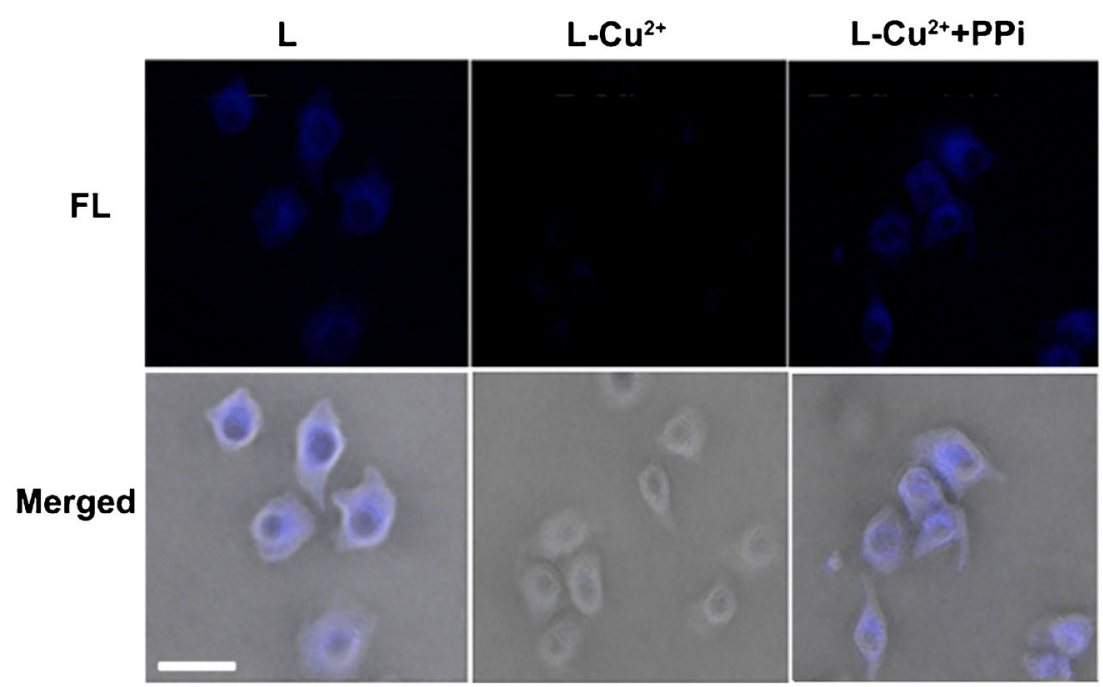

fluorescence images were taken at 30,60, and $120 \mathrm{~min}$ at $37{ }^{\circ} \mathrm{C}$ after inhibitor addition. The results indicated that the $\mathrm{Fl}$ inside the inhibitor-treated cells maintained over the observation time (top row in Fig. 7a and black line in Fig. 7b). However, Fl inside the cells without any pretreatment decreased over time (bottom row in Fig. 7a and red line in Fig. $7 b)$. Above results suggested that the decreased FI in cells without treatment was induced by intracellular ALP which dissociated the $\mathrm{PPi}-\mathrm{Cu}^{2+}$ complex to free $\mathrm{Cu}^{2+}$ to re-chelate with $\mathbf{L}$, turning the fluorescence "Off." With this property, our probe $\mathbf{L}$ could be employed for imaging intracellular ALP activity in living cells pretreated with $\mathrm{Cu}^{2+}$ and PPi.

\section{Conclusion}

In conclusion, we rationally designed a new fluorescent probe (E)-8-((4-methylbenzylidene)amino)napthalen-1-amine (L) for sequential and selective detections of $\mathrm{Cu}^{2+}, \mathrm{PPi}$, and ALP in vitro and in living cells with fluorescence "Off," "On," and
Fig. 7 a Fluorescence imaging of the $\mathrm{Cu}^{2+}$ - and PPi-pretreated HeLa cells incubated with (top row) or without (bottom row) phosphatase inhibitor complex II and imaged at different time points $(0,30,60$, and $120 \mathrm{~min})$. Scale bar: $50 \mu \mathrm{m}$. b FL plots of the cells in A. These experiments were performed in triplicate. Error bars represent standard deviations a

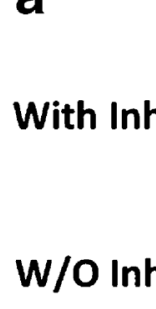

0 min

$30 \mathrm{~min}$
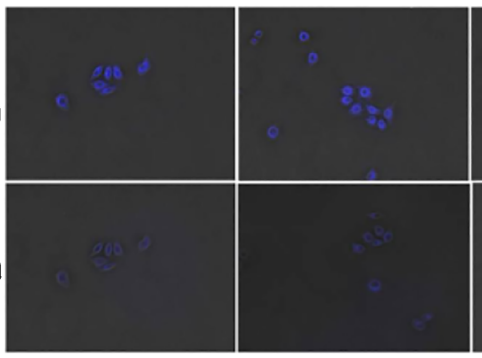

$60 \mathrm{~min}$

$120 \mathrm{~min}$
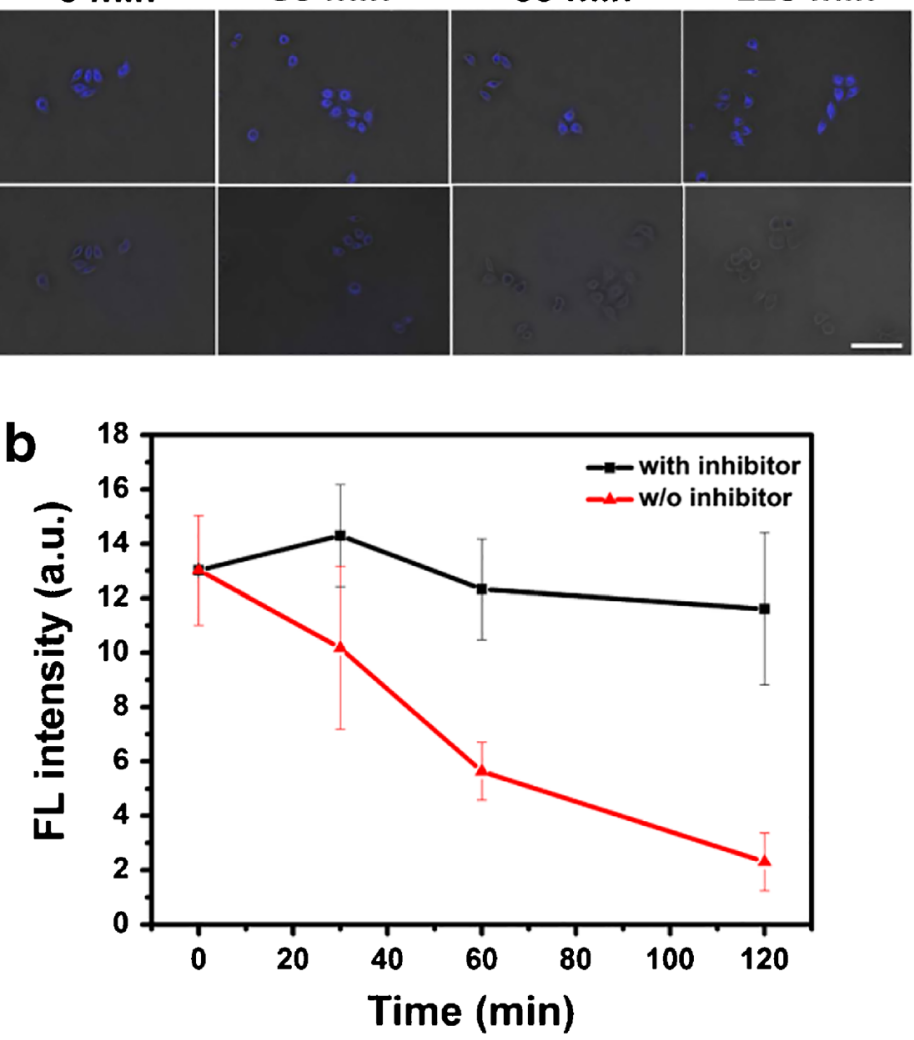
"Off” signals, respectively. The working mechanisms underlying these processes are as follows: (1) chelation between $\mathrm{Cu}^{2+}$ and $\mathbf{L}$ yields the $\mathbf{L}-\mathrm{Cu}^{2+}$ complex, accompanied by fluorescence "Off" due to the LMCT effect; (2) due to the stronger binding affinity of PPi-Cu ${ }^{2+}$ than $\mathbf{L}-\mathrm{Cu}^{2+}$, addition of PPi to the $\mathbf{L}-\mathrm{Cu}^{2+}$ solution dissociates the $\mathbf{L}-\mathrm{Cu}^{2+}$ complex and turns the fluorescence "On"; (3) further added ALP hydrolyzes PPi in the PPi-Cu ${ }^{2+}$ complex, freeing $\mathrm{Cu}^{2+}$ to re-chelate with $\mathbf{L}$ and turn the fluorescence "Off." In physiological solutions, $\mathbf{L}$ was successfully applied for selective detections of $\mathrm{Cu}^{2+}, \mathrm{PPi}$, and ALP in vitro with LODs of $2.60 \mu \mathrm{M}, 0.31 \mu \mathrm{M}$, and $0.05 \mathrm{U} / \mathrm{mL}$, respectively. Moreover, with its property of fluorescence switch, $\mathbf{L}$ was successfully applied to image $\mathrm{Cu}^{2+}$, PPi, and ALP in living HeLa cells. Considering the obvious correlations among $\mathrm{Cu}^{2+}$, PPi (product of ATP), and ALP in Wilson's disease, we envision that our fluorescent probe $\mathbf{L}$ could be applied to in vitro diagnose WD in the near future.

Funding information This work was supported by the Ministry of Science and Technology of China (2016YFA0400904), the National Natural Science Foundation of China (Grants 21725505 and 21675145), and the Science and Technology Department of Zhejiang Province (GF18H180002).

\section{Compliance with ethical standards}

The synovial fluid was obtained from the patients recruited at Ninth People's Hospital, Shanghai Jiao Tong University, School of Medicine, Shanghai. The samples were collected from the patients above 18 years of age who provided written consent and agreed to participate in the study. The protocol of the study was approved by the Ethical Committee of the Ninth People's Hospital, Shanghai Jiao Tong University, School of Medicine, Shanghai, in compliance with the Helsinki Declaration. The protocol used in this study was also approved by the Ethical Committee in Research of the University of Science and Technology of China (protocol number: USTCACUC1801025) assigned by the President of this committee.

Conflict of interest The authors declare that they have no conflicts of interest.

Open Access This article is distributed under the terms of the Creative Commons Attribution 4.0 International License (http:// creativecommons.org/licenses/by/4.0/), which permits unrestricted use, distribution, and reproduction in any medium, provided you give appropriate credit to the original author(s) and the source, provide a link to the Creative Commons license, and indicate if changes were made.

\section{References}

1. Kim B, Nevitt T, Thiele DJ. Mechanisms for copper acquisition, distribution and regulation. Nat Chem Biol. 2008;4:176-85.

2. Ricardo U, Olivares M, Gonzalez M. Essentiality of copper in humans. Am J Clin Nutr. 1998;67:952S-9S.

3. Schleper B, Stuerenburg HJ. Copper deficiency-associated myelopathy in a 45-year-old woman. J Neurol. 2001;248:705-6.

4. Zietz BP, Dieter HH, Lakomek M, Schneider H, Keslergaedtke G, Dunkelberg H. Epidemiological investigation on chronic copper toxicity to children exposed via the public drinking water supply. Sci Total Environ. 2003;302:127-44.
5. Lee S, Choi I, Hong S, Young YI, Lee J, Kang T, et al. Highly selective detection of $\mathrm{Cu}^{2+}$ utilizing specific binding between $\mathrm{Cu}$-demetallated superoxide dismutase 1 and the $\mathrm{Cu}^{2+}$ ion via surface plasmon resonance spectroscopy. Chem Commun. 2009:6171-3.

6. Tokalioğlu Ș, Kartal Ș, Elçi L. Determination of heavy metals and their speciation in lake sediments by flame atomic absorption spectrometry after a four-stage sequential extraction procedure. Anal Chim Acta. 2000;413:33-40.

7. Wu J, Boyle EA. Low blank preconcentration technique for the determination of lead, copper, and cadmium in small-volume seawater samples by isotope dilution ICPMS. Anal Chem. 1997;69: 2464-70.

8. Sarkar S, Pradhan M, Sinha AK, Basu M, Pal T. Selective and sensitive recognition of $\mathrm{Cu} 2+$ in an aqueous medium: a surfaceenhanced Raman scattering (SERS)-based analysis with a low-cost Raman reporter. Chem Eur J. 2012;18:6335-42.

9. Liu J, Lu Y. A DNAzyme catalytic beacon sensor for paramagnetic $\mathrm{Cu} 2+$ ions in aqueous solution with high sensitivity and selectivity. J Am Chem Soc. 2007;129:9838-9.

10. Ganguly A, Paul BK, Ghosh S, Kar S, Guchhait G. Selective fluorescence sensing of $\mathrm{Cu}(\mathrm{II})$ and $\mathrm{Zn}$ (II) using a new Schiff basederived model compound: naked eye detection and spectral deciphering of the mechanism of sensory action. Analyst. 2013;138:6532-41.

11. Mei Y, Bentley PA, Wang W. A selective and sensitive chemosensor for $\mathrm{Cu} 2+$ based on 8 hydroxyquinoline. Tetrahedron Lett. 2006;47: 2447-9.

12. Wang X, Miao Q, Song T, Yuan Q, Gao J, Liang G. A fluorescent switch for sequentially and selectively sensing copper(II) and L-histidine in vitro and in living cells. Analyst. 2014;139: $3360-4$.

13. Jo J, Lee HY, Liu W, Olasz A, Chen CH, Lee D. Reactivity-based detection of copper(II) ion in water: oxidative cyclization of azoaromatics as fluorescence turn-on signaling mechanism. J Am Chem Soc. 2012;134:16000-7.

14. Grinyte R, Barroso J, Díez-Buitrago B, Saa L, Möller M, Pavlov V. Photoelectrochemical detection of copper ions by modulating the growth of CdS quantum dots. Anal Chim Acta. 2017;986:42-7.

15. Fu Y, Ding C, Zhu A, Deng Z, Tian Y, Jin M. Two-photon ratiometric fluorescent sensor based on specific biomolecular recognition for selective and sensitive detection of copper ions in live cells. Anal Chem. 2013;85:11936-43.

16. Gale PA, Gunnlaugsson T. Preface: supramolecular chemistry of anionic species themed issue. Chem Soc Rev. 2010;39:3595-6.

17. Lee HN, Xu Z, Kim S, Swamy KM, Kim Y, Kim SJ, et al. Pyrophosphate-selective fluorescent chemosensor at physiological $\mathrm{pH}$ : formation of a unique excimer upon addition of pyrophosphate. J Am Chem Soc. 2007;129:3828-9.

18. Hirose M, Abe-Hashimoto J, Ogura K, Tahara H, Ide T, Yoshimura T. A rapid, useful and quantitative method to measure telomerase activity by hybridization protection assay connected with a telomeric repeat amplification protocol. J Cancer Res Clin Oncol. 1997;123:337-44.

19. Timms AEZ, Russell YRG, Brown MA. Genetic studies of disorders of calcium crystal deposition. Rheumatology. 2002;41:725-9.

20. Terkeltaub RA. Inorganic pyrophosphate generation and disposition in pathophysiology. Am J Physiol: Cell Physiol. 2001;281: C1-C11.

21. Quinlan E, Matthews SE, Gunnlaugsson T. Colorimetric recognition of anions using preorganized tetra-amidourea derived calix [4] arene sensors. J Org Chem. 2007;72:7497-503.

22. Anzenbacher P, Palacios MA, Jursíková K, Marquez M. Simple electrooptical sensors for inorganic anions. Org Lett. 2005;7: 5027-30. 
23. Su X, Zhang C, Xiao XJ, Xu AQ, Xu ZD, Zhao MP. A kinetic method for expeditious detection of pyrophosphate anions at nanomolar concentrations based on a nucleic acid fluorescent sensor. Chem Commun. 2013;49:798-800.

24. Caltagirone C, Bazzicalupi C, Isaia F, Light ME, Lippolis V, Montis R, et al. A new family of bis-ureidic receptors for pyrophosphate optical sensing. Org Biomol Chem. 2013;11: 2445-51.

25. Zhang JF, Kim SJ, Han JH, Lee SJ, Pradhan T, Cao QY, et al. Pyrophosphate- selective fluorescent chemosensor based on 1,8naphthalimide-DPA-Zn(II) complex and its application for cell imaging. Org Lett. 2011;13:5294-7.

26. Lallès JP. Intestinal alkaline phosphatase: novel functions and protective effects. Nutr Rev. 2014;72:82-94.

27. Goggins S, Naz C, Marsh BJ, Frost CG. Ratiometric electrochemical detection of alkaline phosphatase. Chem Commun. 2015;51:561-4.

28. Zhang L, Hou T, Li H, Li F. A highly sensitive homogeneous electrochemical assay for alkaline phosphatase activity based on single molecular beacon-initiated $\mathrm{T} 7$ exonuclease-mediated signal amplification. Analyst. 2015;140:4030-6.

29. Xiang MH, Liu JW, Li N, Tang H, Yu RQ, Jiang JH. A fluorescent graphitic carbon nitride nanosheet biosensor for highly sensitive, labelfree detection of alkaline phosphatase. Nanoscale. 2016;8:4727-32.

30. Jiang H, Wang X. Alkaline phosphatase-responsive anodic electrochemiluminescence of CdSe nanoparticles. Anal Chem. 2012;84:6986-93.

31. Ruan C, Wang W, Gu B. Detection of alkaline phosphatase using surface-enhanced Raman spectroscopy. Anal Chem. 2006;78: 3379-84.

32. Craig DB, Wong JY, Dovichi NJ. Detection of attomolar concentrations of alkaline phosphatase by capillary electrophoresis using laser-induced fluorescence detection. Anal Chem. 1996;68:697-700.

33. Pei H, Zhu S, Yang M, Kong R, Zheng Y, Qu F. Graphene oxide quantum dots@silver core-shell nanocrystals as turn-on fluorescent nanoprobe for ultrasensitive detection of prostate specific antigen. Biosens Bioelectron. 2015;74:909-14.

34. Liu SY, Pang S, Na W, Su X. Near-infrared fluorescence probe for the determination of alkaline phosphatase. Biosens Bioelectron. 2014;55:249-54

35. Liang J, Yin BC, Wu X, Ye BC. Copper-mediated DNA-scaffolded silver nanocluster on-off switch for detection of pyrophosphate and alkaline phosphatase. Anal Chem. 2016;88:9219-25.

36. Qian ZS, Chai LJ, Huang YY, Tang C, Shen JS, Chen JR, et al. A real-time fluorescent assay for the detection of alkaline phosphatase activity based on carbon quantum dots. Biosens Bioelectron. 2015;68:675-80.

37. Dong L, Miao Q, Hai Z, Yuan Y, Liang G. Enzymatic hydrogelationinduced fluorescence turn-off for sensing alkaline phosphatase in vitro and in living cells. Anal Chem. 2015;87:6475-8.

38. Roelofsen H, Wolters H, Van MJ, Luyn A, Miura N, Kuipers F, et al. Copper-induced apical trafficking of ATP7B in polarized hepatoma cells provides a mechanism for biliary copper excretion. Gastroenterology. 2000;119:782-93.

39. Lee S, Barin G, Ackerman CM, Muchenditsi A, Xu J, Reimer JA, et al. Copper capture in a thioether-functionalized porous polymer applied to the detection of Wilson's disease. J Am Chem Soc. 2016;138:7603-9.

40. Zhang L, Hong MF, Chu ZJ, Xu H, Wang SP, Zhao XJ, et al. A new copper mediated on-off assay for alkaline phosphatase detection based on MoOx quantum dots. Microchem J. 2018;141:170-5.

41. Choi CA, Mazrad ZAI, Ryu JH, In I, Lee KD, Park SY. Membrane and nucleus targeting for highly sensitive cancer cell detection using pyrophosphate and alkaline phosphatase activity-mediated fluorescence switching of functionalized carbon dots.J. Mater. Chem. B.2018; 6: 5992-6001.
42. Dai Y, Liu Z, Bai Y, Chen Z, Qin J, Feng F. A novel highly fluorescent $\mathrm{S}, \mathrm{N}, \mathrm{O}$ co-doped carbon dots for biosensing and bioimaging of copper ions in live cells. RSC Adv. 2018;8: 42246-52.

43. $\mathrm{Hu}$ Y, Geng X, Zhang L, Huang Z, Ge J, Li Z. Nitrogen-doped carbon dots mediated fluorescent on-off assay for rapid and highly sensitive pyrophosphate and alkaline phosphatase detection. Sci Rep. 2017;7:5849.

44. Chen Y, Li W, Wang Y, Yang X, Chen J, Jiang Y, et al. Cysteine-directed fluorescent gold nanoclusters for the sensing of pyrophosphate and alkaline phosphatase. J Mater Chem C. 2014;2:4080-5.

45. Liu H, Jia L, Wang Y, Wang M, Gao Z, Ren X. Ratiometric fluorescent sensor for visual determination of copper ions and alkaline phosphatase based on carbon quantum dots and gold nanoclusters. Anal Bioanal Chem. 2019;411:2531-43.

46. Ma JL, Yin BC, Wu X, Ye BC. Copper-mediated DNA-scaffolded silver nanocluster on-off switch for detection of pyrophosphate and alkaline phosphatase. Anal Chem. 2016;88:9219-25.

47. Wang F, Zhang C, Xue Q, Li H, Xian Y. Label-free upconversion nanoparticles-based fluorescent probes for sequential sensing of $\mathrm{Cu} 2+$, pyrophosphate and alkaline phosphatase activity. Biosens Bioelectron. 2017;95:21-6.

48. Zhao J, Wang S, Lu S, Sun J, Yang X. A luminescent europiumdipicolinic acid nanohybrid for the rapid and selective sensing of pyrophosphate and alkaline phosphatase activity. Nanoscale. 2018;10:7163-70

49. Malik AH, Hussain S, Tanwar AS, Layek S, Trivedi V, Iyer PK. An anionic conjugated polymer as a multi-action sensor for the sensitive detection of $\mathrm{Cu} 2+$ and $\mathrm{PPi}$, real-time ALP assaying and cell imaging. Analyst. 2015;140:4388-92.

50. Panditha A, Bhattarai KR, Siddappaa KG, Chaeb HJ, Seo YJ. Novel fluorescent C2-symmetric sequential on-off-on switch for $\mathrm{Cu} 2+$ and pyrophosphate and its application in monitoring of endogenous alkaline phosphatase activity. Sens Actuator B-Chem. 2019;282:730-42.

51. Zhang C, Gao B, Zhang Q, Zhang G, Shuang S, Dong C. A simple Schiff base fluorescence probe for highly sensitive and selective detection of $\mathrm{Hg} 2+$ and $\mathrm{Cu} 2+$. Talanta. 2016;154:278-83.

52. Das K, Patra C, Sen C, Datta A, Massera C, Garribba E. EPR interpretation, magnetism and biological study of a $\mathrm{Cu}(\mathrm{II})$ dinuclear complex assisted by a schiff base precursor. J Biol Inorg Chem. 2017:22:481-95.

53. Naskar B, Modak R, Maiti DK, Drew MB, Bauzá A, Frontera A. A Schiff base platform: structures, sensing of $\mathrm{Zn}$ (II) and PPi in aqueous medium and anticancer activity. Dalton Trans. 2017;46:9498510.

54. Tang XL, Peng XH, Dou W, Mao J, Zhang JR, Qin W, et al. Design of a semirigid molecule as a selective fluorescent chemosensor for recognition of Cd(II). Org Lett. 2008;10:3653-6.

55. Willson RA, Clayson KJ, Leon S. Unmeasurable serum alkaline phosphatase activity in Wilson's disease associated with fulminant hepatic failure and hemolysis. Hepatology. 1987;7:613-5.

56. Zhang Q, Shi L, Meng X. Deep adsorption desulfurization of liquid petroleum gas by copper-modified bentonite. RSC Adv. 2016;6: 9589-97.

57. Kobayashi Y, Ishida S, Ihara K, Yasuda Y, Morita T, Yamada S. Synthesis of metallic copper nanoparticles coated with polypyrrole. Colloid Polym Sci. 2009;287:877-80.

58. Jung HS, Kwon PS, Lee JW, Kim JI, Hong CS, Kim JW, et al. Coumarin-derived $\mathrm{Cu} 2+$-selective fluorescence sensor: synthesis, mechanisms, and applications in living cells. J Am Chem Soc. 2009;131:2008-12. 
59. Feng X, An Y, Yao Z, Li C, Shi G. A turn-on fluorescent sensor for pyrophosphate based on the disassembly of $\mathrm{Cu} 2+-$ mediated perylene diimide aggregates. ACS Appl Mater Interfaces. 2012;4:614-8.
Publisher's note Springer Nature remains neutral with regard to jurisdictional claims in published maps and institutional affiliations. 